\title{
EVOLUÇÃo FILOSÓFICA DO CONCEITO DE DIGNIDADE HUMANA
}

\author{
[PHILOSOPHICAL EVOLUTIONS OF THE CONCEPT OD HUMAN DIGNITY]
}

\author{
José Francisco de Assis Dias * \\ Gabriel Jasper Kracieski ** \\ Universidade Estadual do Oeste do Paraná, Brasil
}

Resumo: A presente pesquisa trata do tema hoje chamado de dignidade da pessoa humana, mas que por vezes será tratado apenas como dignidade ou dignidade humana. Esta variação se dá pelas épocas e autores abordados. Daqui o objetivo geral: analisar a evolução históricofilosófica do conceito de dignidade humana. Dessa forma, coloca-se o seguinte problema a ser elucidado: como se deu a evolução histórica e filosófica da ideia de dignidade humana, nos autores escolhidos como máximos representantes de sua época? E, diante de tal problema, será investigada a evolução do conceito de dignidade humana no ocidente, partindo da antiguidade até a contemporaneidade, buscando trabalhar os mais relevantes autores e obras que contribuíram para a edificação do conceito tema desta pesquisa. Além disso, pretende-se investigar a importância da dignidade humana na atualidade, em âmbito internacional. A escolha de tal tema é justificada pelo fato de o conceito "dignidade humana" ter se tornado o "princípio dos princípios" de muitos ordenamentos jurídicos hodiernos. Para a realização da pesquisa, utilizara-se a Pesquisa Bibliográfica. A partir deste artigo, é possível compreender cada passo histórico e filosófico que contribuíram para a formação do conceito de dignidade da pessoa humana, que hoje possui caráter universalista e abraça a todos da família humana. Isto é, percebe-se, através dessa pesquisa, que o conceito amplamente
ABSTRACT: This research deals with the theme today called human dignity, but which will sometimes be treated only as human dignity or dignity. This variation is due to the periods and authors covered. Hence the general objective: to analyze the historical-philosophical evolution of the concept of human dignity. Thus, the following problem arises to be elucidated: how did the historical and philosophical evolution of the idea of human dignity take place, in the authors chosen as maximum representatives of their time? And, in the face of such a problem, the evolution of the concept of human dignity in the West will be investigated, starting from antiquity to contemporary times, seeking to work with the most relevant authors and works that contributed to the construction of the theme concept of this research. In addition, it is intended to investigate the importance of human dignity today, at the international level. The choice of such a theme is justified by the fact that the concept of "human dignity" has become the "principle of principles" of many modern legal systems. To carry out the research, Bibliographic Research was used. From this article, it is possible to understand each historical and philosophical step that contributed to the formation of the concept of human dignity, which today has a universal character and embraces everyone in the human family. That is, it is clear, through this research, that the concept widely used in the legal world

* Professor Adjunto da UNIOESTE, Campus de Toledo-PR; Coordenador do curso de Licenciatura em Filosofia. Doutor em Filosofia pela Pontifícia Universidade Urbaniana, Cidade do Vaticano, Roma, Itália (2008).Email: prof.dias.br@gmail.com.** Universidade Estadual do Oeste do Paraná-UNIOESTE.E-mail: gabrieljasper6@gmail.com 
utilizado no mundo jurídico como um supraprincípio, não surgiu no pós-Segunda Guerra Mundial, apenas foi ali que migrou definitivamente para o mundo jurídico, mas sim que o conceito surgiu e vem sendo debatido a mais de dois milênios. Nesse sentido, também, nota-se que nem sempre a dignidade da pessoa humana foi atribuída à todos os espécimes da raça humana, e que pela maior parte do tempo de sua construção, a dignidade pertenceu a grupos específicos das sociedades, ora ligada a honra, ora ligada a títulos de nobreza, ora à pessoa cuja vida era levada conforme os ensinamentos divinos. Somente em Kant consagrou-se a dignidade da pessoa humana como atributo inerente a cada ser racional, e ainda mais tarde, com o movimento constitucionalista da segunda metade do século XX, que esse conceito migra ao Direito e passa a proteger o homem não só com seu conteúdo moral, mas também com seu conteúdo normativo.

Palavras-Chave: Dignidade Humana; Pessoa Humana; Direitos Humanos as a supra-principle, did not appear in the postWorld War II era, it was only there that it definitively migrated to the legal world, but that the concept arose and has been debated for more than two millennia. In this sense, it is also noted that the dignity of the human person was not always attributed to all specimens of the human race, and that for most of the time of its construction, the dignity belonged to specific groups of societies, now linked to honor, now linked to titles of nobility, now to the person whose life was led according to divine teachings. Only in Kant was the dignity of the human person consecrated as an inherent attribute of every rational being, and even later, with the constitutionalist movement of the second half of the twentieth century, that this concept migrates to Law and starts to protect man not only with its moral content, but also with its normative content.

KeYwords: Human Dignity; Human Person; Human rights

\section{INTRODUÇÃO: IDADE CRISTÃ NO MEDIEVO}

$\mathrm{O}$ presente artigo trata do tema hoje chamado de dignidade da pessoa humana, e tem por objetivo geral analisar a evolução histórico-filosófica do conceito de dignidade humana. Dessa forma, coloca-se o seguinte problema de pesquisa: Como se deu a evolução histórica e filosófica da ideia de dignidade humana, desde a antiguidade clássica até os dias atuais?

Para isso, será necessário a investigação da evolução do conceito de dignidade humana no ocidente, partindo dos Gregos até a atualidade, bem como apresentar brevemente a realidade histórica de cada obra filosófica trabalhada e, por fim, investigar a importância da dignidade humana na atualidade, em âmbito internacional. Assim, utilizaremos a pesquisa bibliográfica como método de investigação científica.

Pesquisar como se deu essa evolução valorativa e conceitual de um termo hoje tido no Brasil como 'o princípio dos princípios' constitucionais ${ }^{1}$, é entender melhor o caminho da história de como o Direito e a filosofia olharam para o homem ao longo do tempo. A partir desse entendimento, justifica-se a relevância dessa pesquisa, no sentido de que, a partir dela, sejamos melhor capacitados a considerar a dignidade humana em nosso âmago para atribuir valor a cada vida humana, sem exceções, além de podermos aplicar o princípio na prática do Direito de forma mais adequada, de forma a não ocorrer a 'banalização' desse conceito, como adverte Barroso (2016, p. 23).

$\mathrm{O}$ atual ministro do Supremo Tribunal Federal elucida, de forma muito didática, essa possibilidade de banalização do conceito: explica que por ser um princípio constitucional, a dignidade da pessoa humana se tornou uma ideia muito atraente, e por isso se torna recorrente invocá-la em situações que não tenha necessariamente uma violação ao núcleo essencial de direitos e valores contidos nessa ideia. Isto é, mesmo sendo um 'supraprincípio' constitucional, sua aplicabilidade não pode se tornar fútil, de 
tal sorte que entender melhor o conceito, bem como sua evolução histórico-filosófica, é um meio de não cometer tal equívoco. Por conseguinte, a justificação da relevância desse estudo surge não só pelo fato de a dignidade da pessoa humana ser princípio constitucional brasileiro a partir da Constituição Federal de 1988, mas também, e principalmente, pelo fato de o conceito ter se tornado um grande norteador valorativo do homem, sendo aplicado em decisões difíceis do Direito, além de ser princípio basilar na forma predominante de pensamento do século XXI, e de ter sido objeto de atenção de diversos filósofos ao longo da história.

Obtém-se, por meio dessa pesquisa, meios para analisar criticamente usos (e desusos) do conceito de dignidade da pessoa humana atualmente. Não obstante, no curso da investigação percebe-se a morosidade da construção de um valor humano, até o mesmo se tornar justo (ou chegar mais perto disso, ao menos). Aproximadamente dois milênios de reflexões e de construções filosóficas foram necessárias até que, conceitualmente, a dignidade da pessoa humana ganhasse um conteúdo totalmente universalista, com a filosofia moral de Imannuel Kant, expressa sobretudo em sua obra 'A fundamentação da Metafísica dos Costumes', por meio da formulação de um imperativo categórico que considera cada ser racional como um fim em si mesmo. Para além disso, percebe-se que foram necessários mais dois séculos de história para que, de alguma forma, essa filosofia moral kantiana ganhasse algum teor normativo, de forma a efetivamente garantir, por meio de Estados Democraticamente constituídos e suas instituições, proteção à dignidade da pessoa humana.

Frisa-se aqui que, apesar do título do artigo pressupor dois ângulos para se olhar ao conceito de dignidade da pessoa humana (histórico e filosófico), um terceiro ângulo de preocupação não poderia se deixar de lado: o jurídico. É incompleta a pesquisa que trata da dignidade da pessoa humana e não considera que a atribuição valorativa que uma sociedade possui em relação ao ser humano reflete diretamente no direito construído por essa sociedade. Quando dignidade humana é relacionada à qualquer característica acidental (e não substancial) do ser humano, o conceito é excludente, e abraça somente àqueles agraciados com nobreza (como em Roma), ou os de pele clara (em sociedades racistas), ou os de raça ariana (como no regime nazifascista). Em todos os casos em que isso acontece, o resultado é o mesmo: a degradação humana.

Atualmente, a construção e o debate acerca do conceito de dignidade humana não findaram. Discussões sobre o conteúdo de direitos contidos na ideia de dignidade da pessoa humana, sobre a amplitude normativa do conceito, sobre a melhor forma de conciliar um conceito que permite garantias tão amplas (e moralmente incontestáveis) aos indivíduos com os recursos notadamente escassos de um Estado, além de debates mais filosóficos relacionados com a biotecnologia, a eventual possibilidade de criação de bebês de prancheta e de alteração no genoma humano suscitam discussões sobre a natureza humana e a sua dignidade da pessoa humana.

\section{A VIDA PÚbliCA E A DIGNIDADE NA GRÉCIA ANTIGA}

A Grécia antiga não era unificada, e sim composta por cidades-estados, sendo que cada uma delas possuía seu próprio sistema de governo, de economia e suas próprias leis. Em Atenas, vivia-se numa Democracia direta entre 508 a.C. e 404 a.C., isto é, não havia votação para representantes. O sistema funcionava como um 'sorteio', e os homens livres (eupátridas) sorteados iriam votar determinado projeto/acusação, ou ainda poderiam propor novas leis. Contudo, para ser cidadão em Atenas, era preciso que o indivíduo fosse homem livre, ateniense, filho de pai e mãe ateniense, e ter ao menos 
21 anos (ROSSET, 2008, p. 193). Ainda havia a 'classe' dos metecos (estrangeiros); os escravos; e as mulheres e crianças. Visivelmente, os homens livres eram minoria em Atenas.

Em meio a essa estrutura social, onde todos os cidadãos possuíam direitos políticos, mas nem todos os habitantes eram cidadãos, a noção de dignidade ateniense estava ligada à posição social ocupada pelo indivíduo. Como poderia um escravo ser mais digno que um eupátrida? Ou, como poderia um eupátrida de 21 anos e que ainda não participou ativamente da vida pública ser tão digno quanto um cidadão ancião e que muito contribuiu para a polis ateniense? Era essa a forma de se pensar a dignidade, sendo ela completamente atrelada à importância que os Gregos depositavam na vida pública:

No pensamento filosófico e político da Antiguidade Clássica, reconhecia-se a noção de dignidade, mas, sobretudo, associada à posição ou ao conceito protagonizado na esfera da vida pública, evidenciando-se, assim, pelo título eminente que se ostentasse; pelo cargo ou alta função na qual se estivesse investido; pela honra e pelo grau de reconhecimento pelos demais membros da comunidade. $\mathrm{O}$ cerne da noção clássica de dignidade não residia, dessarte, no valor individual do homem, em sua autonomia subjetiva; tratava-se de uma espécie de dignidade publicizada ou socializada, cotada, sobretudo, em referência ao papel social na consecução do bem comum e do progresso comunitário e à participação política do cidadão na vivência e nos destinos coletivos da pátria. (PARENTE; REBOUÇAS, s.d., p. 10)

Consoante com Renner (2016, p. 1) “A reflexão filosófica clássica elaborava um significado para a dignidade humana fundada na posição ocupada pelo indivíduo na sociedade, assim como o seu grau de reconhecimento pelos demais membros da sociedade". Contudo, esse modo de reconhecimento de dignidade a partir de uma posição defronta-se com a possibilidade de 'desumanizar' as pessoas com menores posições sociais, principalmente em uma polis onde a maioria da população era composta por escravos, que eram pessoas vistas como posse, e nada mais.

Não obstante, Aristóteles, filósofo grego que viveu na democracia ateniense, escreve em sua Política uma justificativa argumentativa para a existência da escravidão: "Aquele que por natureza não pertence a si, mas a outro homem, é por natureza um escravo. E uma coisa possuída pode ser definida como instrumento de ação, separada de seu senhor" (ARISTÓTELES, 2010, Livro I, Cap. IV). Já no V capítulo, prossegue: "Entre os seres, desde o nascimento, alguns estão destinados ao comando, e outros à obediência [...]"; e conclui: "Fica claro, então, que alguns homens são por natureza feitos para ser livres e outros para ser escravos, e que para esses últimos a escravidão é tanto útil quanto justa". Não se pretende aqui 'criticar' Aristóteles pelos trechos, buscase, ao invés disso, através dos fragmentos de seu livro, entender melhor como a sociedade grega pensava, e como a dignidade era concebida por ela.

A dignidade grega era "dignidade", mas não dignidade humana. Ainda longe de conferir um valor próprio a cada ser humano, a sociedade berço da Filosofia pensava a dignidade como podendo ser conquistada ao longo da vida através de feitos, de cargos ocupados, e da participação na vida política, mas que também poderia ser perdida ou retirada, em caso da perda do status social e da notoriedade pública.

\section{A DIGNIDADE HUMANA NO MUNDO ROMANO ANTIGO}

Os romanos desenvolveram-se e são reconhecidos pelo seu processo de 
conquista de outros povos e territórios, bem como pelo grande intervalo de tempo onde a sociedade romana existiu e 'sobreviveu'. Nesse contexto de conquista, o primeiro aspecto que se torna importante para o entendimento da Roma antiga é a escravidão, principalmente escravos de guerra. Como assinala Castro (2014, p. 94), escravos eram coisa - res -, e como tal, estavam sujeitos ao seu senhor, que detinha sobre ele poder de caráter jurídico absoluto. A noção de dignidade em uma sociedade com esse olhar para o escravo certamente não será de caráter universal; afinal, como o seria, tendo em vista que as pessoas em situação de escravidão eram tratadas como 'res' até mesmo pelo Direito vigente na época?

É nesse sentido que, num primeiro momento, de forma semelhante aos Gregos, a dignidade - dignitas - está ligada à posição na esfera da vida pública. Contudo, destaca Becchi (2009, p. 2), quando a locução "dignidade humana" adquire relevância filosófica no mundo romano, um outro significado também é empregado no termo, significado este que diz respeito à posição especial do homem no cosmos. Nessa perspectiva a obra Dos Deveres, de Cícero, é crucial para o entendimento dessa dupla acepção supracitada.

Marco Túlio Cícero foi um advogado, político, escritor e filósofo romano. Também foi considerado um dos maiores oradores da Roma antiga. Cícero foi eleito cônsul em 63 a.C., durante a República Romana. Sua obra De Officiis foi a última obra filosófica escrita por Cícero, na qual ele formula os valores políticos e éticos da sociedade romana, além de - e aqui o porquê do interesse na obra - tratar da dignidade do homem.

O vocábulo dignidade, usado por Cícero, possui relação com os feitos públicos e com o bem-estar social: "Pode-se viver bem, com dignidade e altivez, sendo, ao mesmo tempo, simples, sincero e útil aos semelhantes" (Livro I, cap. XXVI), bem como se refere à honra: "Da mesma forma se vê a fortaleza: toda a ação corajosa, toda a ação viril, é digna de um grande coração e está posta segundo a dignidade [...]" (Livro I, cap. XXVII); e à virtude: "Toda a virtude é acompanhada de certa dignidade, e que, se se pode separar uma de outra, é mais pelo pensamento que na realidade: pois não é possível separá-las como não se pode separar a beleza da saúde" (Livro I, cap. XXVII); ainda escreve: "Necessitamos ter por todos os homens um certo respeito, sobretudo para com os honestos [...]" (Livro I, cap. XXVIII).

Esse conjunto de apresentações se enquadram numa primeira acepção da dignidade do homem, aquela que diz respeito a uma posição sócio-política individual, onde também coexiste um sentido moral, visto que se pode extrair valores como a honestidade, integridade e virtude de seus trechos (SARLET, 2009, p. 33). De acordo com essa acepção particularista, é possível falar em uma quantificação e modulação da dignidade, no sentido de se admitir a existência de pessoas mais dignas ou menos dignas, conforme tanto o aspecto moral do indivíduo quanto a sua posição política e social ocupada na comunidade.

Por outro lado, paralela a uma dignidade relativa e particularista, Cícero admite também uma dignidade em sentido universalista, isto é, atribuindo um valor imanente a todos os seres humanos, por sermos todos partícipes da razão. Vista dessa maneira, a dignidade decorre do homem ser o único animal racional, e isso, portanto, nos coloca no topo da hierarquia do mundo natural, fato este gerador da condição de detentores de dignidade humana. Essa dualidade de acepções é explícita em seu texto, onde Cícero (2001) afirma:

Lembre-se que a natureza nos deu dupla personalidade: uma, comum a todos nós, porção de razão e dignidade que nos eleva acima dos animais, princípio de todos 
os nossos deveres, e de onde derivam o que se chama dignidade e decência: a outra, própria de cada um de nós. (Livro I, cap. XXX)

Com isso, é evidente que Cícero dá um salto no sentindo da universalização da dignidade. Ainda que de forma 'secundária', visto que na maioria das vezes a dignidade é sinônimo de honra ou decorre de uma situação sócio-política individual, o autor admite uma característica (a razão) que atribui valor igualmente aos homens e que os coloca em posição especial no universo, e é essa significação que coloca Cícero na lista dos precursores desse tão importante conceito para o homem até os dias de hoje.

\section{A DIGNIDAdE HUMANA NO CRISTIANISMO MEDIEVAL}

Ainda no mundo antigo, a doutrina cristã trouxe consigo uma afirmação potencial ao valor universal da dignidade humana. É através dela que se retira o entendimento de que todos os homens (e não somente os eleitos) são feitos à imagem de Deus - imago $d e i^{2}$. Tal semelhança é o que fundamenta a posição privilegiada do homem no cosmos, que só é reforçada quando Deus se faz homem em Jesus Cristo (BECCHI, 2008, p. 3).

\subsection{O conceito de 'Pessoa'}

Antes do Cristianismo, não havia no grego ou no latim uma palavra que se assemelha ao significado de 'pessoa'. Essa inexistência se explica pelo fato de que, na cultura clássica, não era reconhecido o valor do indivíduo enquanto tal: seu valor era expresso através do grupo ao qual pertencia, da família de qual era parte, do patrimônio que a família tinha e de sua raça (MOURA, 2002, p. 77).

No início da Idade Média, contudo, Severino Boécio criou um conceito de pessoa e que repercute, posteriormente, na filosofia teológica de São Tomás de Aquino. Boécio define a pessoa como 'substância individual de natureza racional' (SARLET, 2015, p. 252). Essa afirmação é retomada por Tomás de Aquino na Suma Teológica³. O Aquinate explica que além dessa natureza racional, o homem é substância que existe por si, e que, exatamente graças a sua racionalidade, também age por si:

O particular e o indivíduo realizam-se de maneira ainda mais especial e perfeita nas substâncias racionais que têm o domínio de seus atos e não são apenas movidas na ação como as outras, mas agem por si mesmas. Ora, as ações estão nos singulares. Por isso, entre as outras substâncias, os indivíduos de natureza racional têm o nome especial de pessoa. (AQUINO, 2016, 1, 29, 1, C)

Nessa ótica, Strefling (2016, p. 3) interpreta que, para Tomás, o conhecimento e a liberdade são as características intrínsecas à pessoa. 'Pessoa' é o termo cunhado para abrigar aquele cuja existência foi obra-prima de Deus, agraciado com a racionalidade e a liberdade, a pessoa pode cunhar sua vida, decidir sobre ela, ter a capacidade de entender o mundo e de se autodeterminar (MARTINS; GODINHO, 2012, p. 17).

Além disso, vale ressaltar que a pessoa é composta por corpo e alma. A alma não é espirito puro porque não pode por si só realizar tudo, não tem sensações, e isso a impede de constituir por si só uma pessoa (STREFLING, 2016, p. 6). Tomás de Aquino deixa isso expresso na passagem "O homem não é só alma, nem só corpo, mas afirmamos que ele é simultaneamente alma e corpo" (AQUINO, 2016, 1, 75, 6 resp). 


\subsection{A dignidade cristã no medievo}

Como dito no início do capítulo, é através da crença Cristã de que o home foi feito à imagem e semelhança divina, que o homem (ou a pessoa) adquire sua dignidade. Nesse sentido, se o homem é que foi feito à sua imagem e semelhança, e não somente os Cristãos, se extrai a consequência lógica de que todo homem é dotado de um valor próprio e intrínseco (SARLET, 2009, p. 32).

Em uma passagem de Paulo de Tarso, fica ainda mais evidente a referida universalização do homem perante a religião, não os distinguindo por atributos sociais, de origem ou gênero: "Não há judeus ou gentio, nem escravos ou libertos, nem homens ou mulheres, pois todos vocês são um só em Jesus Cristo" (Gálatas, 3, 28).

Mais a fundo, Tomás de Aquino fundamenta a dignidade da pessoa não somente na universalista concepção cristã do homem como imagem e semelhança de Deus. Para ele, ainda, a dignidade também é originada na capacidade de autodeterminação humana, em virtude de sua natureza racional. É através dessas características que a pessoa pode criar sua relação com Deus, e portanto, também é através dessas que o homem se torna merecedor de um valor intrínseco, chamado de dignidade (MARTINS; GODINHO, 2012, p. 23-24; PARENTE; REBOUÇAS, s. d., p. 9; SARLET, 2015, p. 252).

Santos e Campos (2016, p. 26-30) fazem uma análise pontual: O humanismo do Aquinate, elevando o ser humano a categoria de criatura digna de respeito e de valor, a partir do reconhecimento da paternidade divina e da afirmação da pessoa como imago dei é ontológica, mas também é ética. A partir dessas premissas ontológicas, não há espaço para ideologias totalitárias, não há espaço para manifestação da cultura da morte (aborto, pena de morte etc.), não há espaço para o desrespeito com o próximo, não há espaço para a irresponsabilidade com o semelhante, enfim, não há espaço para nenhum ato que desconsidere ética e ontologicamente o ser humano como uma pessoa ligada à Deus, e que, sendo criação dele, não pode ser violada, desrespeitada ou tratada de forma indigna. Todo homem tem responsabilidades com o seu criador, com o Deus todo poderoso, e maltratar outro homem, é maltratar um filho de Deus, ferindo a responsabilidade do agente tanto para com a deidade, quanto para com o seu semelhante.

A concepção Cristã da dignidade da pessoa corrobora em muito para a universalização do conceito. Por outro lado, é importante pontuar a dicotomia entre doutrina e prática no que diz respeito à Igreja Católica. A doutrina universalista e acolhedora já fora apresentado. A Igreja, como instituição, contudo, por várias vezes esteve em desacordo com princípios e ensinamentos bíblicos, ao passo que já apoiou a escravidão e perseguiu os 'hereges', por exemplo (BARROSO, 2016, p. 16).

\section{Giovanni Pico Della Mirandola (1463-1494)}

Giovanni nasceu em Mirandola, nasceu na Itália, em 24 de fevereiro de 1463. Veio de uma família nobre; desde cedo foi 'preparado' para uma vida eclesiástica, teve acesso a diversas Universidades, aprendeu latim, grego e estudou direito canônico, contudo, abandonou-o para estudar Filosofia. Tornou-se, na época, um dos mais notáveis representantes do Humanismo Renascentista. Em Roma, em dezembro de 1486, publicou De hominis dignitate oratio (Discurso sobre a Dignidade do Homem). O texto foi preparado como abertura soleníssima do confronto entre Pico e a banca de juízes romanos que o julgariam, tendo como causa 13 de suas 900 teses publicadas anteriormente no mesmo ano, que foram condenadas pela Igreja. É daí que se 
desprendem as características do discurso, principalmente sua honorável retórica.

Pico vive "entre o crepúsculo medieval e o alvorecer da Idade Moderna" na expressão de Feracine (1985, p. 16), ou seja, uma época ainda muito marcada e influenciada pela poderosa Igreja Católica, mas também época onde a figura do homem ganha relevância, e passa a ser o centro das atenções na corrente humanista, esta que recupera, enobrece e exalta, ao pódio máximo da dignidade e do respeito, o homem. Nesse sentido, o Discurso de Pico é o primeiro a abordar, mesmo que de forma breve, a dignidade humana.

Para o autor, a dignidade do homem se dá por dois aspectos: o primeiro por ser o homem a criação final, a obra prima pensada por Deus; o segundo por sermos livres e não pré-determinados, por sermos perfectíveis. Quanto ao primeiro deles, Pico já assinala no começo de seu discurso: "[se referindo a Deus na criação da Terra] [...] ao término de seu labor, desejava o Artífice que existisse alguém capaz de compreender o sentido de tão grande obra, que amasse sua beleza e contemplasse a sua grandiosidade" (1985, p. 39). E nesse sentido que Miràndola afirma que o lugar especial do homem em sua criação, juntamente com essa porção de consciência dada por Deus, compõe a dignidade em seu primeiro aspecto.

Contudo, o primeiro aspecto seria quase trivial, se fosse só, pois Pico estaria muito próximo de somente reproduzir o pensamento Católico. A questão para Pico consistia em buscar um atributo humano que o elevasse à condição de "a maior das maravilhas saídas da mão do Criador, ou seja, o que há no homem de único, específico e estupendo" (FERACINE, 1985, p. 24).

Nesse sentido, onde o autor inova é em seu segundo e mais importante aspecto: aquele que diz respeito à liberdade humana. A liberalidade arbitrária faz do ser humano a única obra de Deus ainda (e para sempre) inacabada. Ao ter feito sua obra final, Deus concede ao homem um passe livre, e o presenteia com racionalidade e consciência. Pico exclama (1985, p. 40) "Ó suprema liberalidade de Deus Pai, ó suma e maravilhosa beatitude do homem! A ele foi dado possuir o que escolhesse; ser o que quisesse". O renascentista elabora, ainda, um discurso proferido pelo Criador a Adão, de forma que fica inequívoco o que pretende expressar:

[...] tomou então o homem, essa obra de tipo indefinido, e tendo-o colocado no centro do universo, falou-lhe nestes termos: a ti, ó Adão, não te temos dado nem uma sede determinada, nem um aspecto peculiar, nem um múnus singular precisamente para que o lugar, a imagem e as tarefas que reclamas para ti, tudo isso tenhas e realizes, mas pelo mérito de sua vontade e livre consentimento.

As outras criaturas já foram prefixadas em sua constituição pelas leis por nós estatuídas.

Tu, porém, não estás coarctado por amarra nenhuma. Antes, pela decisão do arbítrio, em cujas mãos depositei, hás de predeterminar a tua compleição pessoal.

Eu te coloquei no centro do mundo, a fim de poderes inspecionar, daí, de todos os lados, da maneira mais cômoda, tudo que existe. Não te fizemos nem celeste nem terreno, mortal ou imortal, de modo que assim, tu por ti mesmo, qual modelador e escultor da própria imagem segundo tua preferência e, por conseguinte, para tua glória, possas retratar a forma que gostarias de ostentar. (MIRANDOLA, 1985, p. $39,40)$

A dignidade humana está, de acordo com o excerto de Giovanni, nessa capacidade inventiva e de auto aprimoramento, neste para sempre inacabado e 
indefinido ser humano, nesta imperfeição, que ao contrário do resto das imperfeições do Universo, tem um vasto caminho limpo como margem de perfectibilidade, e não depende somente do acaso genético ou físico para poder se transformar. Deus coloca o ser humano no centro do universo e não lhe atribui um ofício limitado ou privativo, mas sim lhe confere uma vastidão de potencialidades, a fim de que no exercício de sua vida, cada ser humano identifique e cumpra com sua própria missão existencial. O habitante do centro do universo criado por Deus é feito de forma a ser agente individual de sua própria história (FERACINE, 1985, p. 25).

Contudo, Pico ainda não abandona o que Gregos e Romanos trouxeram: justamente porque a dignidade advém de um processo construtivo, ela pode ser retirada pela força dos atos humanos. Antes, a 'ascensão' e a 'decadência' da dignidade estavam ligadas à vida pública, à honra e ao reconhecimento social, agora, o que muda é a próxima ligação com o Deus católico, a vida religiosa, e com a filosofia, a dedicação e o empenho com a verdade.

Nesse sentido, duas passagens do Discurso de Pico são extremamente clarificadoras: "Poderás descer ao nível dos seres mais baixos e embrutecidos; poderás, ao invés, por livre escolha da tua alma, subir aos patamares superiores, que são divinos" (1985, p. 40); e ainda:

Se vires alguém envolto nos múltiplos enganos da fantasia, qual outro Calipso, aliciado por sub-reptícia sedução ou dominado pelos sentidos, então trata-se de um ser irracional e não foi ao homem que vistes. Se, em contrapartida, ao filósofo que, com reta razão, discerne todas as coisas, se a ele venerares, então és um ente celeste e não terreno. (MIRANDOLA, 1985, p. 41)

Faz-se importante pontuar que para Pico, nessa dinâmica do processo de dignificação e busca pela perfeição enquanto humano detentor de racionalidade, é que o homem necessita da Filosofia (FERACINE, 1985, p. 19). Pico avança na história conceitual e na forma de pensar a dignidade do homem. Ele concebe, mesmo que acompanhado da possibilidade de perca de dignidade a partir de atos próprios, um atributo dignificador do ser humano que está presente em cada um da nossa espécie: a liberdade natural. Pico aponta, ainda de forma muito interligada à Igreja, para a consciência individual, e, portanto, para a liberdade de ação e decisão sobre a própria existência, como sendo autossuficiente para dignificar o homem.

\section{A DIGNIDADE hUMANA EM IMMANUEL KANT (1724-1804)}

A transição do mundo medieval para o moderno trouxe consigo uma mudança na forma de percepção do mundo. Essa mudança, que começa no renascimento, ainda no século XV, com uma corrente humanista, vem a desaguar nos séculos XVII e XVIII através do racionalismo e Iluminismo, de tal forma que o lugar antes ocupado por Deus e pela religião, agora é ocupado pelo homem, que se torna a fonte de sentido da realidade. Eis o surgimento do homem moderno. Nas palavras de Sarlet (2009, p. 35), a concepção de dignidade humana passa por um 'processo de racionalização e laicização' na modernidade.

Nesse contexto, um dos grandes representantes da modernidade e de sua nova forma de olhar para o homem e para o mundo é Immanuel Kant (1724-1804), que, dentre várias outras contribuições, produziu uma filosofia ética que, inicialmente, dignifica todo e qualquer homem, incondicionalmente.

Mesmo que antecedido por diversos outros filósofos na tentativa de dignificação do homem, é Kant - ou melhor, a sua filosofia - que marca a ruptura do conceito de 
dignidade humana atrelado a Deus. O filósofo alemão torna, definitivamente, em sua obra Fundamentação da metafísica dos costumes, a dignidade humana um conceito laico, e pertencente a priori ao homem, sendo ela assentada sobre a razão prática e a autonomia ética inerente ao ser humano.

$\mathrm{Na}$ obra em questão, Kant se propõe a investigar qual é o princípio, por excelência, regulador da conduta humana. Esse princípio, para que tenha valor moral e possua obrigatoriedade, deve possuir valor universal, e para tanto não deveria ser buscado na natureza humana ou nas condições do mundo em que ele está inserido, mas simplesmente a priori em conceitos da razão pura (KANT, 2018, p. 27). Isso significa, portanto, que o princípio edificador da moral deverá ser desvinculado de quaisquer circunstâncias culturais, contextos históricos, sociais, políticos e de toda e qualquer influência externa que a 'razão pura' pode sofrer:

Por isso uma metafísica dos costumes é estritamente necessária, não só em razão da especulação, para se pesquisar a fonte dos princípios práticos existes a priori na nossa razão, mas também porque os costumes em si permanecem submetidos a todo tipo de deterioração, enquanto faltar a eles esse fio condutor, a regra mais elevada do seu julgamento correto. [...] Em sua pureza e autenticidade, a lei moral não deve ser buscada em nenhum outro lugar a não ser numa filosofia pura, portanto essa metafísica deve precedê-la, pois sem ela não pode haver, em lugar algum, uma filosofia moral. (KANT, 2018, p. 27 e 28)

A inconstância do mundo empírico é o que determina a necessidade dessa desvinculação do princípio em relação a ele, de tal forma que tomar qualquer característica desse mundo metamórfico como fundamento da moral faria com que o fundamento perdesse completamente sua validade, seu conteúdo e sua universalidade. Isto é, o princípio moral, segundo Kant, deve conduzir as ações dos seres racionais, e não as ações e as condições dos mesmos que devem criar o princípio supremo da moral.

Esse princípio, por ser um mandamento, Kant o chamará de imperativo. Os imperativos se dividem em hipotéticos e categórico: os hipotéticos dizem respeito a mandamentos para que um agente racional atinja uma finalidade específica; já o imperativo categórico é universal e necessário, de tal forma que vale para todos os seres racionais, ao mesmo tempo que não almeja nenhum fim específico, isto é, no caso do imperativo categórico, não é o resultado da ação guiado por ele que é levado em conta, mas sim, a forma e o princípio de que ele mesmo resulta. Sobre essa diferença nas finalidades dos imperativos, Kant elucida:

Se a ação é boa apenas como um meio para alguma outra coisa, então o imperativo é hipotético; mas se ela é apresentada como boa em si, necessária numa vontade conforme a razão e como o princípio dessa vontade, então o imperativo é categórico. (KANT, 2018, p. 56)

Além disso, outra característica distingue os imperativos entre si: o hipotético não pode ser considerado uma lei prática, visto que, ao almejar um objetivo específico, o imperativo hipotético está condicionado a ele de tal forma que, caso haja renúncia do mesmo, o imperativo hipotético não mais se aplica ou possui validade. De forma contrária a esse caso, o imperativo categórico possui teor de lei prática pelo justo motivo de que não pode ser renunciado, pois, sendo um mandamento incondicional, impede a vontade de atuar a seu sabor (KANT, 2018, p. 62).

Desdobra-se, a partir disso, que, diante de um imperativo categórico, um sujeito racional está, por obrigação, submetido a agir em conformidade com ele, ainda que sua vontade não seja absolutamente boa. Isso significa que, a autonomia da vontade em 
Kant é uma 'via de mão dupla'. Por um lado, considera-a claramente como o que confere nobreza e dignidade a todo sujeito racional, conferindo ao mesmo o 'título' de membro legislador no Universo (KANT, 2018, p. 78 e 82). De outro lado, contudo, a autonomia da vontade está submetida à necessidade de se agir conforme a lei moral universal (Kant chamará a essa necessidade de dever) (KANT, 2018, p. 82). O não alinhamento entre vontade, através de sua máxima, e o mandamento moral universal, obriga o indivíduo racional a agir conforme o dever, enquanto a vontade alinhada com o mandamento moral universal faz com que a pessoa seja não só submetida a essa lei, como também legisladora em relação a ela. É nesse sentido que a autonomia da vontade e sua capacidade de elevar os seres racionais à condição de legislador universal é o que dignifica o homem.

Vencida a parte conceitual dos imperativos, Kant (2018, p. 63) enuncia a primeira formulação do imperativo categórico: “Aja como se a máxima de sua ação devesse tornar-se, pela sua vontade, uma lei universal da natureza". É esse o comando moral que, se respeitado, faz com que nossas ações sejam moralmente boas. É este o verdadeiro 'cânone' das nossas ações morais (KANT, 2018, p. 66). Utilizando-se do mesmo exemplo didático de Kant, se uma pessoa, em virtude de dificuldades financeiras, pede dinheiro emprestado, e para consegui-lo jura que irá conseguir pagar, quando na verdade sabe que não conseguirá, e tentar transformar isso em máxima universal como exercício de verificação de moralidade de sua ação, irá perceber que essa máxima jamais poderia ter valor de lei universal, visto que se assim fosse, a confiança entre as pessoas deixaria de existir, e jamais alguém emprestaria dinheiro para outrem, mesmo sob juramento de devolução futura (KANT, 2018, p. 64-65). Nesse sentido, o supracitado imperativo impediria ações imorais todas as vezes que, antes de tomar uma ação, um ser racional o tomasse por mandamento moral.

No entanto, é na segunda enunciação do imperativo categórico que reside a maior contribuição de Kant no que diz respeito à dignificação do homem - e, portanto, onde reside o maior interesse dessa pesquisa: "Aja de modo a usar a humanidade, tanto na sua pessoa quanto na pessoa de outrem, a todo instante e ao mesmo tempo como um fim, mas jamais apenas como um meio" (KANT, 2018, p. 71). Tal enunciação do imperativo categórico nos mostra que, para além de dignificar o homem, impedindo qualquer ação arbitrária contra ele, a ética de Kant também é universalista, e a primeira que, amplamente abraça todos os espécimes humanos como sendo intrinsecamente dignos, isto é, sem, para tal, recorrer à religião ou a algum outro fator externo ao humano.

A dignidade, nesse sentido, está para os seres racionais assim como o preço está para as coisas. Preço se dá ao que é substituível por outro semelhante, por isso o preço é relativo. Já a dignidade marca um valor intrínseco (BARROSO, 2016, p. 71). Marca tudo aquilo que, por sua natureza, é insubstituível, que não pode ser 'coisificado', tudo aquilo que, nas palavras de Kant, são fim em si mesmo. Disso decorre que o tratamento injusto, trapaceiro, mentiroso, enganoso, mutilador ou destruir com outro ser humano denota 'coisificá-lo'. Ao tratar cada ser humano como um fim, é injuntivo que, em hipótese nenhuma alguma classe, credo ou raça serão menosprezados; não haverá quantificação de qualidades do ser humano a fim de considerar alguns mais e outros menos dignos; não há como considerá-los meros objetos para alcançar um fím próprio.

Além do mais, caso a vontade não seja totalmente boa, de forma a ponderar um tratamento indigno para com outro ser humano, a ética de Kant impera que, nesse caso, atue-se conforme o dever, isto é, a necessidade de se respeitar o imperativo categórico, e assim, considerar cada ser humano como fim em si mesmo. É a partir disso que Kant sustenta que o princípio da humanidade em geral como fim em si é a maior condição 
restritiva da liberdade das ações de toda pessoa (KANT, 2018, p. 73).

Ainda nos resta a terceira formulação do imperativo categórico, qual seja: "Aja de tal maneira que tua vontade possa encarar a si mesma, ao mesmo tempo, como um legislador universal através de suas máximas" (KANT, 2018, p. 74). Nessa última formulação, Kant chama a atenção para o fundamento último da ação conforme a lei universal: que pode ser o dever, ou a boa vontade. Se agimos conforme o dever, agimos porque 'temos' que o fazer. Agir conforme o dever significa que, mesmo a vontade me estimule, me faça querer outra coisa, através da minha natureza racional, sei que devo agir conforme a lei universal. Quando agimos conforme o dever, nossa ação é meramente ajustada à lei moral, e não em prol dessa. Agir em prol da lei moral significa, então, que o fundamento da ação conforme a lei universal é a boa vontade, criada pela razão prática. Agir pela boa vontade significa agir porque a razão, além de alcançar o entendimento do que é a máxima universal, também produziu uma boa vontade, de forma que a máxima da ação do agente racional é condizente com a máxima universal. A partir desse momento, ele não mais é um subordinado da legislação universal, mas sim um membro legislador dela. Ou, dito de outra forma, o agente racional passa a ser subordinado da lei cujo ele mesmo pode ser considerado autor (KANT, 2018, p. 73-75).

Podemos concluir, nessa ótica, que a noção de dignidade kantiana se difere das noções da antiguidade e da Idade média, na medida em que assenta o valor no homem apenas e tão somente pelo fato de ser homem, livre, e possuidor de autonomia subjetiva. Por isso, a dignidade humana reside em cada espécime humano, a partir do reconhecimento de que todos eles possuem seu valor individual e intrínseco. "Intrínseco" significa dizer que o homem não mais carece de prestígio social, ou de ser 'imago dei', o homem não mais carece de dignificação externa a si, pois já é digno em si mesmo.

\section{A DIGNIDAdE DA PESSOA HUMANA NA CONTEMPORÂNEIDADE}

Como recém visto, no âmbito filosófico foi Kant quem revolucionou a forma de se considerar a dignidade da pessoa humana. No âmbito histórico, contudo, é a Revolução Francesa, ancorada nos princípios iluministas, ao quebrar com o regime monárquico absolutista, o acontecimento que marca o processo de busca pela universalização dos direitos individuais (os chamados direitos liberais). Tendo como 'assombração' o recente regime absolutista, os franceses se preocupavam com a garantia de direitos do indivíduo em face ao Estado, defendendo uma "área de autonomia individual na qual o Estado não poderia intervir" (GUERRA, 2013, p. 67). Surgem então os direitos negativos, que nada mais são do que uma proibição, um dever de abstenção do Estado em relação a algumas liberdades asseguradas aos indivíduos.

A noção de direitos humanos surge principalmente, na França, com a Declaração de direitos do homem e do cidadão de $1789^{5}$, contudo, ela ainda é vaga, e apesar de trazer outros ideais democráticos (como a ideia de soberania popular- art. $3^{\circ}$; e a igualdade perante a lei - art. $6^{\circ}$ ), o direito mais expressamente positivado na declaração diz respeito às liberdades individuais (arts. $1^{\circ}, 2^{\circ}, 4^{\circ}, 11^{\circ}, 14^{\circ}$ ). Nas palavras de Bobbio (2004, p. 79), a declaração foi o "atestado de óbito do Antigo Regime, destruído pela revolução".

A interpretação da Revolução Francesa e sua importância para a consolidação da democracia contemporânea é crucial para a compreensão do tema. Bobbio explica, em seu artigo $A$ herança da grande revolução, que historicamente a relação política entre 
governantes e governados sempre se deu de forma desigual, sendo estes submetidos às exigências daqueles, de modo que a lei (mandamento do soberano), é superior, vem antes do direito do indivíduo, antes da liberdade. Nessa ótica política, qualquer direito ou esfera de liberdade individual que resta aos indivíduos, é tido como 'benesse' dos detentores de poder, como algo que lhes foi concedido pelo(s) soberanos. O filósofo político italiano ainda acrescenta que esse cenário se sustenta a partir de uma concepção orgânica da sociedade, a qual ele denominará de 'modelo aristotélico', onde todos os indivíduos são tidos como animais políticos, que nascem já em determinado grupo social, e moldam-se à polis e ao seu funcionamento (BOBBIO, 2004, p. 105-107).

Acontece que, com a Revolução de 1789, houve uma inversão dessa perspectiva. O homem é nesse momento considerado livre ao nascer, graças às teorias dos contratualistas, que o consideravam como um indivíduo em si e fora de círculos sociais e políticos. Disso decorre que, mesmo que numa formulação hipotética do Estado de Natureza, o homem passou a ser visto primariamente como indivíduo (antes de ser 'encaixado' em algum grupo social/político), e nessa condição, o Estado deveria respeitá-lo, de forma a não intervir nesse espaço de autonomia que o homem já possui desde o nascimento ${ }^{6}$. Está completa a inversão de valores entre governante e governado: não é mais aquele que 'concede' a este alguns direitos ou liberdades, mas é este que, no exercício da sua cidadania, constrói e legitima o Estado, que por sua vez deve, em cada um e todos seus atos, respeitar o espaço de liberdade individual que pertence a todos os indivíduos, sem exceção. Para Bobbio, a democracia só é possível com essa inversão de valores, tanto que afirma (BOBBIO, 2004, p. 109): "A democracia moderna repousa na soberania não do povo, mas dos cidadãos", e (BOBBIO, 2004, p. 110) "Se a concepção individualista da sociedade for eliminada, não será mais possível justificar a democracia como uma boa forma de governo". Não restam dúvidas, portanto, de que a Revolução Francesa, juntamente com os ideais que carregava e com a Declaração de 1789 foram cruciais para a consolidação de uma 'primeira fase' de direitos humanos.

Nessa que é considerada a primeira dimensão dos Direitos Humanos, a liberdade, a propriedade e a segurança passam a ser os valores de maior monta, claramente como forma de evitar um 'novo Regime Absolutista', de forma que o Estado é submisso às regras do Direito, mas principalmente, da economia, como assinala Bastos (2011, p. 251).

Paralelamente a isso, entretanto, com as revoluções industriais e o crescimento econômico de boa parte da Europa entre os séculos XVIII e XIX, um cenário diverso emerge: a população urbana cresce desordenadamente; as cidades não oferecem condições básicas de higiene; há uma maior disseminação de doenças e descabida espoliação dos operários ${ }^{7}$. Sobre esse quadro histórico, afirma Bastos (2011, p. 252):

O final dos 1700 e os 1800, seguramente, foram marcados por um período de: 1 . Vivência máxima do capitalismo moderno, 2. Valorização sem limites da propriedade privada e do individualismo, 3. Da espoliação de uma classe trabalhadora, cuja venda de trabalho era sua única forma de participação no mercado, 4. De lutas sociais sangrentas, 5. Subserviência acentuada do Estado à 'mão invisível' do mercado, 6. Ausência de prestações positivas, por parte do Estado, em favor dos administrados, dentre outros aspectos.

Esse quadro geral depõe contra ideais de direitos humanos e de qualquer acepção de dignidade humana que se possa retirar dos ideais franceses, liberais ou até mesmo da Declaração de direitos do homem e do cidadão de 1789. Nesse novo, mas infeliz quadro histórico, a dignidade humana não mais se concretizava com a mera 
concessão estatal de liberdade e com princípios de não-intervenção estatal (direitos negativos), e agora passa a ser idealizada também como uma garantia, uma prestação do Estado (direitos positivos) para com o indivíduo no que diz respeito ao trabalho, educação e saúde, por exemplo (GUERRA, 2013, p. 67).

Em outras palavras, visando reparar as eventuais falhas do mercado, corrigir 148 seus excessos e proteger a sociedade, difunde-se a ideia de um 'capitalismo social'. É nesse momento que nasce o Estado Social. A ideia de direitos humanos e de dignidade humana é vinculada também a direitos sociais e o 'campo de garantias' contido na ideia de direitos humanos cresce significativamente. Concretiza-se, portanto, a considerada segunda dimensão dos direitos humanos ${ }^{8}$.

O século XX, por sua vez, traz consigo duas Guerras Mundiais, ainda em sua primeira metade. A Segunda Guerra Mundial, a mais cruel e genocida delas, sobretudo por causa do regime nazista alemão, causou à Humanidade horrores e sofrimentos indizíveis. Enxergou-se nesse período o desprezo, o desrespeito e a deterioração do homem pelo próprio homem, os direitos humanos foram completamente esquecidos e desconsiderados.

No final da Segunda Guerra Mundial, o conceito de dignidade humana, que aparece na antiguidade e ganha sua maior e a ainda válida acepção em Kant, é introduzido com grande força no Direito, sobretudo nos textos de direitos das gentes e nas constituições nacionais desde então (HABERMAS, 2012, p. 9). Num esforço para a reconstrução de um mundo moralmente devastado pelo totalitarismo e pelo genocídio, a dignidade humana foi importada como um dos pilares para uma "longamente aguardada era de paz, democracia e proteção dos direitos" (BARROSO, 2016, p. 18-19).

Habermas explica a importância dada à dignidade humana após a Segunda Guerra Mundial afirmando que "[...] as experiências cumulativas de dignidade violada formam uma fonte de motivação moral para a práxis constitucional" (HABERMAS, 2012, p. 19). Ora, qual maior violação da dignidade poderia existir, além do Holocausto? Aparentemente, difícil encontrar exemplos. Nessa ótica, a propagação do conceito da dignidade humana dentro do movimento Constitucional da segunda metade do século XX, bem como sua aplicação jurídica e vinculação aos direitos das gentes parece corroborar com a tese pontual do filósofo alemão. E, não parando por aí, Habermas $(2012$, p. 14) propõe que a cada nova violação social à dignidade de alguém, o conceito filosófico e jurídico ganharia maior apelo moral e consequentemente maior legitimação jurídica.

Em meio a esse cenário de reconstrução de todo o mundo, a Organização das Nações Unidas - ONU (1945) personificou a consciência da humanidade que fora ultrajada durante a guerra, e através da Declaração Universal dos Direitos do Homem (1948), assinalou a fundação do movimento atual dos direitos humanos. Em seu Preâmbulo, a dignidade humana é citada duas vezes:

Considerando que o reconhecimento da dignidade inerente a todos os membros da família humana e dos seus direitos iguais e inalienáveis constitui o fundamento da liberdade, da justiça e da paz no mundo. [...] Considerando que, na Carta, os povos das Nações Unidas proclamam, de novo, a sua fé nos direitos fundamentais do homem, na dignidade e no valor da pessoa humana [...]. A assembleia geral proclama a presente Declaração Universal dos Direitos do Homem como ideal comum a atingir por todos os povos e todas as nações [...].

É justamente graças a essa Declaração que, aponta Bobbio (2004, p. 46), o problema do reconhecimento dos direitos humanos passou, pela primeira vez na história humana, da esfera nacional para a internacional, fato esse que implica no envolvimento 
e na consideração de todos os povos como sendo dignos, e sendo assim, cada Estado possui como obrigação de proteger e conferir esses direitos humanos:

Com a declaração de 1948, tem início uma terceira e última fase, na qual a afirmação dos direitos é, ao mesmo tempo, universal e positiva: universal no sentido de que os destinatários dos princípios nela contidos não são mais apenas cidadãos deste ou daquele Estado, mas todos os homens; positiva no sentido de que põe em movimento um processo em cujo final os direitos do homem deverão ser não mais apenas proclamados ou apenas idealmente reconhecidos, porém efetivamente protegidos até mesmo contra o Estado que os tenha violado. (BOBBIO, 2004, p. 29-30)

O período que sucede a Segunda Guerra Mundial, justamente por ter sido recentemente devastado pelo totalitarismo, foi extremamente fértil na criação de Constituições democráticas e Tratados internacional de direito humanos. Tendo como base e inspiração a Declaração de 1948, esses documentos políticos e jurídicos começaram a difundir e institucionalizar / judicializar o princípio da dignidade humana .

Depois de mais de 2000 anos 'vagando' como um conceito filosófico, a dignidade da pessoa humana tornou-se também um conceito jurídico. Habermas (2012, p. 17-18) explica essa migração indicando a 'elasticidade' do conceito:

[...] a dignidade humana forma algo como o portal por meio do qual o conteúdo igualitário-universalista da moral é importado ao direito. A ideia da dignidade humana é a dobradiça conceitual que conecta a moral do respeito igual por cada um com o direito positivo e com a legislação democrática de tal modo que, na sua cooperação sob circunstâncias históricas favoráveis, pôde emergir uma ordem política fundamentada nos direitos humanos.

Um exemplo histórico da judicialização do conceito da dignidade humana é a própria existência e atuação do Tribunal de Nuremberg, criado para julgar os coautores do holocausto. Ao invocarem o respaldo do direito positivo existente no regime nazifascista para justificar seus atos ${ }^{10}$, tais indivíduos não foram absolvidos pelo Tribunal, ao contrário, foram condenados por crime de lesa Humanidade, tendo infringido, para tanto, a dignidade da pessoa humana, inerente a cada pessoa, e por isso, anterior a qualquer positivação (ZENNI, 2011, p. 20).

A dignidade da pessoa humana, carregada filosoficamente com o preceito kantiano, hoje atua em relação aos direitos humanos com uma dupla significação: a primeira, se refere ao fato de que a dignidade humana inerente a cada pessoa é base e fonte dos direitos humanos; a segunda, mostra a dignidade como conteúdo dos direitos humanos, isto é, é aquilo pelo qual os direitos humanos existem, é aquilo que eles protegem (WALDRON, 2007, p. 203).

A fundamentação da necessidade de existência e respeito à dignidade da pessoa humana e aos direitos humanos é um problema tido como resolvido hodiernamente. $\mathrm{O}$ desafio parece residir em como protegê-los. Nesse sentido, inúmeras são as discussões jurídicas e políticas sobre qual seria a melhor forma de conferir exequibilidade a essas conquistas morais e filosóficas, de forma que elas também se tornem conquistas sociais e políticas.

\section{CONSIDERAÇÕES FINAIS}

A dignidade humana no ocidente surge na sociedade grega antiga como atributo 
daqueles que participavam da vida pública - o que consistia numa radical minoria da população ateniense. Em Roma, essa acepção continua em vigor, com o adendo que uma nova acepção surge: a do ser humano como ocupantes de um lugar privilegiado no cosmos, em virtude de sua natureza racional. Contudo, é com o cristianismo que uma ideia universalista de dignidade é melhor assentada, qual seja, a de que todo ser humano foi feito à imagem e semelhança de Deus, e, sendo filhos do ser supremo, todos humanos possuem um valor intrínseco e que carecem de respeito. Ainda ligado à ideia Cristã, mas já no período Renascentista, Pico Della Mirandola exclama a dignidade humana por sermos a obra prima da Criação divina, e também pela capacidade humana de autodeterminação.

Até aqui, todas as definições possuem algum 'defeito' valorativo: quanto as concepções de caráter excludentes, não se é preciso dizer muito; A de Cícero, uma concepção secundária de dignidade, visto que a primeira e mais comentada era a de uma dignidade atrelada à participação na vida pública; a concepção Cristã, se lhe pode tecer críticas no que diz respeito à atuação da Igreja, que por muitas vezes não foi condizente com a doutrina, e que, portanto, perde certa legitimação ao proclamar o homem como imago dei; Mirandola, por sua vez, como foi demonstrado, tece a possibilidade de o ser humano descer ao nível da irracionalidade, através de ações imorais e não condizentes com a fé Cristã.

É Immanuel Kant o predecessor do universalismo da dignidade humana, segundo atributos que lhe são próprios (diferente de uma dignidade dependente do homem ser a imagem de Deus). Proclamando o homem como um fim em si mesmo e uma teoria moral invejável, Kant mais tarde irá emprestar seu vocabulário às declarações internacionais de direitos humanos e às Constituições democráticas, que acabam por transpor ao mundo normativo o que antes pertencia ao mundo filosófico. Eis a consagração da dignidade da pessoa humana.

Ainda, é devido à essa transposição ao mundo jurídico que atualmente as maiores discussões acerca da dignidade da pessoa humana dizem respeito à sua eficácia normativa, ou sobre quais devem ser os direitos assegurados e em que medida em nome da dignidade humana. Talvez, esse seja o maior desafio do direito contemporâneo: conciliar a efetivação de um princípio moralmente incontestável e que por isso se tornou o 'princípio dos princípios', com a notável escassez dos recursos estatais. É conciliar o ideal com o possível. A filosofia com a política. Contudo, que jamais saia da ótica a ilegitimidade de qualquer discussão sobre o tema que não considere a todo e a cada momento o ser humano como um fim em si mesmo.

\section{REFERÊNCIAS}

TOMÁS DE AQUINO. Suma Teológica: volume 1, I ${ }^{a}$ Pars. Tradução de Alexandre Correia. Campinas, SP: Ecclesiae, 2016.

ARISTÓTELES. Política. $5^{\circ}$ ed., $4^{\circ}$ reimpressão. São Paulo: Martin Claret, 2010.

BARROSO, Luís Roberto. A dignidade da pessoa humana no direito constitucional contemporâneo: a construção de um conceito jurídico à luz da jurisprudência mundial. Tradução de Humberto Laport de Mello. $4^{\circ}$ reimpressão. Belo Horizonte: Fórum, 2016.

BASTOS, Elísio Augusto Velloso. Algumas reflexões sobre os direitos humanos e suas gerações. In: PIOVESAN, Lages; GARCIA, Maria (org.). Teoria Geral dos Direitos Humanos: Doutrinas essenciais, v. 1. São Paulo: Editora Revista dos Tribunais, 2011, p. 239-266.

BECCHI, Paolo. O princípio da dignidade humana. In: Revista Brasileira de Estudos Constitucionais. vol. 7, jul./set. 2008.

Bíblia. Tradução portuguesa da vulgata latina pelo padre Antônio Pereira de Figueiredo. $1^{\mathrm{a}}$ ed. São Paulo: Rideel, 1997. 
BOBBIO, Norberto. A era dos direitos. Trad. Carlos Nelson Coutinho. Rio de Janeiro: Elsevier, $13^{\circ}$ reimpressão, 2004.

CASTRO, Flávia Lages de. História do Direito Geral e Brasil. $10^{\circ}$ edição, $2^{\circ}$ tiragem. Rio de Janeiro: Lumen Juris, 2014.

CÍCERO. Dos Deveres. Trad. Alex Martins. São Paulo: Martin Claret, 2001.

FERACINE, Luiz. Introdução. In: MIRÀNDOLA, Giovanni Pico Della. A dignidade do Homem. São Paulo: Escala, 1985.

GUERRA, Sidney. Direitos Humanos: Curso elementar. São Paulo: Saraiva, 2013.

HABERMAS, Jürgen. Sobre a Constituição da Europa: um ensaio. Trad. Denilson Luiz Werle, Luiz Repa e Rúrion Melo. São Paulo: UNESP, 2012.

KANT, Immanuel. Fundamentação da metafísica dos costumes. Trad. Inês A. Lohbauer. São Paulo: Martin Claret, 2018.

MARTINS, Antonio H. C; GODINHO, Ariele A. O diálogo entre os Direitos Humanos e sua fundamentação filosófica na Teoria Moral de Tomás de Aquino. Revista Ética e Filosofia Política - $\mathrm{N}^{\mathrm{o}} 15$ - Volume 2 - Dez. de 2012. Disponível em $<$ https://periodicos.ufjf.br/index.php/eticaefilosofia/article/view/17723>. Acesso: 03 de jun. de 2020.

MIRÀNDOLA, Pico Della. A dignidade do Homem. São Paulo: Escala, 1985.

MOURA, Laércio Dias de. A dignidade da pessoa e os direitos humanos. Rio de Janeiro: PUC, 2002.

NUNES, Luiz Antônio Rizzato. O princípio constitucional da dignidade da pessoa humana. São Paulo: Saraiva, 2002.

PARENTE, Analice Franco Gomes; REBOUÇAS, Marcus Vinícius Parente. A construção histórica do conceito de dignidade da pessoa humana. Disponível em $<$ http://www.publicadireito.com.br/artigos/?cod=066d47ae0c1f736b $>$. Acesso: 16 de jun. de 2020.

RENNER, Fabio Krejci. A evolução histórica da dignidade humana. 2016. Disponível em $<$ https://fabiorenner.jusbrasil.com.br/artigos/410576918/a-evolucao-historica-dadignidade-humana $>$. Acesso: 15 de maio de 2020.

ROSSET, Luciano. A democracia ateniense: filha de sua história, filha de sua época. Revista de Cultura Teológica. v. 16, n. 64. jul/set 2008. Disponível em $<$ https://revistas.pucsp.br/index.php/culturateo/article/viewFile/15535/11601>. Acesso: 08 de jun. de 2020.

SANTOS, Ivanaldo dos; CAMPOS, Sávio L. de Barros. TOMÁS DE AQUINO E O HUMANISMO. Revista A Ordem. Vol. 100, No. 1, 2016. Disponível em $<$ http://www.revistaaordem.com.br/index.php/aordem/article/view/5/5>. Acesso: $01 \mathrm{de}$ jun. de 2020 .

SARLET, Ingo Wolfgang. Dignidade da pessoa humana e direito fundamentais na Constituição Federal de 1988. $7^{\circ}$ Ed. Porto Alegre: Livraria do Advogado. 2009.

SARLET, Ingo Wolfgang. Notas Sobre a Dignidade (da pessoa) Humana no Âmbito da Evolução do Pensamento Ocidental. Revista Opinião Jurídica. Fortaleza, n. 17, p.249-267, jan./dez. 2015.

Disponível

em $<$ https://periodicos.unichristus.edu.br/opiniaojuridica/article/view/265>. Acesso: 03 de jun. de 2020.

SREFLING, Sérgio Ricardo. A realidade da pessoa humana em Tomás de Aquino. Editora PUCRS, 2016. Disponível em <https://editora.pucrs.br/anais/seminario-internacional-deantropologia-teologica/assets/2016/20.pdf $>$. Acesso: 03 de jun. de 2020.

WALDRON, Jeremy. Dignity and rank. European journal of sociology. v. 48, n. 2, p. 201-237, ago./dez. 2007.

ZENNI, Alessandro Severino Valler; FILHO, Daniel Ricardo Andreatta. O direito na perspectiva da dignidade humana: transdisciplinariedade e Contemporaneidade. Porto Alegre: Sergio Antonio Fabris Editor, 2011.

Notas

1 Nas palavras de Rizzato, o princípio da dignidade humana “[...] é um verdadeiro supraprincípio 
constitucional que ilumina todos os demais princípios e normas constitucionais e infraconstitucionais." (NUNES, 2002. p. 50-51).

2 A famosa passagem bíblica de Gênesis diz que: "Então Deus disse: "Façamos o homem à nossa imagem e semelhança. Que ele reine sobre os peixes do mar, sobre as aves dos céus, sobre os animais domésticos e sobre toda a terra, e sobre todos os répteis que se arrastem sobre a terra." Deus criou o homem à sua imagem; criou-o à imagem de Deus." (Gênesis, $1,26-27)$

3 "Pessoa é a substância individual de natureza racional. Pessoa significa o que há de mais perfeito em toda natureza, a saber, o que subsiste em uma natureza racional." (AQUINO, 2016, I, 29, 3)

4 Coisificar aqui é usado no sentido de 'tornar um meio', tornar uma coisa. A expressão é apropriada do uso feito por Zenni e Filho em "O Direito na Perspectiva da Dignidade Humana: Transdisciplinariedade e Contemporaneidade.” Porto Alegre: Sergio Antonio Fabris Editor, 2011.

5 É necessário assinalar que o documento não foi o primeiro nesse sentido. Em 1776, também com ideais liberais, foi promulgada a Declaração de Independência dos Estados Unidos da América, que tutela como inalienáveis os direitos da vida, o de liberdade e o de buscar a felicidade.

6 Segundo Bastos (2011, p. 240), é o jusnaturalismo que oferece a ideia de postulados supra positivos que orientariam e limitariam o poder, possibilitando a teoria contratualista, que por sua vez fundamentou, juntamente como o Iluminismo, o processo revolucionário.

7 Essa espoliação era caracterizada pela insalubridade no local de trabalho, baixíssima remuneração, excesso de horas trabalhadas por dia, crianças e grávidas trabalhando nessas condições e expostas ao perigo, dentre outros fatores.

8 Sobre a teoria das dimensões dos direitos humanos, alguns esclarecimentos: ao 'classificar' os direitos humanos, a validade da classificação é puramente explicativa ou conceitual, visto que os direitos humanos são tidos como um só corpo. Além disso, a existência de dimensões não gera nenhuma relação de prevalência ou de uma sobre a outra. Tratam-se de 'caminhos diversos' para alcançar e efetivar a dignidade humana, caminhos esses que surgiram de acordo com o contexto histórico em questão, como explicitado no texto.

Ainda, cabe considerar que atualmente se fala em uma terceira dimensão, que conteria em seu 'rol de direitos' os direitos ligados a fraternidade e solidariedade, como por exemplo o direito à autodeterminação dos povos e o direito ao meio-ambiente estável.

9 Alguns exemplos constitucionais: Na Lei Fundamental da República Federal da Alemanha, de 1949, no artigo $1^{\circ}$, consta: "A dignidade da pessoa humana é inviolável. Respeitá-la e protegêlla é obrigação de todo o poder público.”; O art. 1 da Constituição Portuguesa, de 1976, estatui que "Portugal é uma República soberana, baseada na dignidade da pessoa humana e na vontade popular e empenhada na construção de uma sociedade livre, justa e solidária"; Na Constituição Italiana de 1947, em seu art. 41, instaura-se: "A iniciativa económica privada é livre. A mesma não se pode desenvolver em contraste com a utilidade social ou de uma forma que possa trazer dano à segurança, à liberdade e à dignidade humana." Na Constituição Brasileira de 1988 (art. 1º, III), a dignidade da pessoa humana é um dos fundamentos do Estado Democrático de Direito da República Federativa do Brasil.

Quanto aos tratados, podemos citar, além do preâmbulo da Declaração Universal dos Direitos do Homem de 1948, o Pacto Internacional sobre os Direitos Econômicos, Sociais e Culturais e o Pacto Internacional sobre os Direitos Civis e Políticos, ambos de 1966, que mencionam os 'direitos iguais e inalienáveis do homem' como decorrentes da dignidade da pessoa humana.

10 Cf. O caso mais famoso do tribunal, escrito por Hannah Arendt em sua obra "Eichmann em Jerusalém: um relato sobre a banalidade do mal”. 